\title{
The Assassins: ancestors of modern Muslim suicide bombers?
}

\author{
Salam Abdulqadir Abdulrahman \\ College of Law \& Political Science - University of Human Development, KRG, Iraq
}

\begin{abstract}
This article examines the methods and motivations of suicide assassination of the Assassins and draws similarity between them and modern Muslim suicide bombers. Current literature about suicide bombing often focuses on socio, economic and political factors and describes it as a revenge for injustice and bad conditions of life in general. This article does not deny the fact that there can be multiple motives and factors behind the individuals who commit acts of suicide bombing and that there are always political gains for the organisers, however it highlights the main driving force which is religion and a strong belief in the afterlife pleasure that motivates individuals to end their lives and the lives of others.

This article attempts to find ancestors for modern Muslim suicide bombers in an order called the Assassins lived from the eleventh to thirteenth centuries. The significance of this finding lies in the fact that there is something deep about suicide bombing; the Assassins lived in an environment very different from ours, yet they practiced suicide assassinations for a very long time. Agents of the Assassins were going through a long process of indoctrination and they were motivated by Paradise upon death.

In this article the history of this order is reviewed while their assassination activity is underscored. The article brings some examples from modern suicide bombers and highlights their similarities to the Assassins. It relies on the secondary sources available about the subject.

One finding is that there might be political gains for the organisers of suicide assassination or suicide bombing but for the individuals committing the act it is more the idea of Paradise and afterlife pleasure that drive them toward it. Thereby this article has its own contribution to the literature by makes recommendation to how to fight the root of this problem.
\end{abstract}

Index Terms - Assassins / assassination / suicide murdering / suicide bombing / Paradise

\section{INTRODUCTION}

This article analyses the core activity of the Order of the Assassins, a militant order in the north of modern Iran and the Levant from the eleventh to thirteenth centuries. It demonstrates that suicide assassination was practiced in the medieval times by a radical Muslim order against high-profile Muslim figures and against
Christians as well. This article is an attempt to show that modern suicide bombing is a new but more dangerous form of suicide assassination because the same factor is mainly behind the attacks. So this article is an attempt to answer the question of why some individual Muslims use their bodies as weapons, carry explosive belts and killing themselves and others together.

We look for the answer of this question mainly in the activity of this order which existed about a thousand years ago as we see in it volunteers going on suicide missions. So our hypothesis is that the root of suicide bombing lies mainly in the ideology the bombers hold about what awaits them when they die, although socio, economic and political factors facilitate and play important roles.

Recent literature available about suicide bombing is taking us more toward a wider area of investigation including the social, cultural, economic and political backgrounds of suicide bombers and the wider political suppression and repression in the area. This is a good and productive approach in itself but it should not obscure the fact that religious ideology and certain way of interpreting religious texts can overwhelm many other factors and send individuals to suicide bomb themselves. This research aims at highlighting this issue and attempts to attract future researchers' attention toward it.

Suicide bombing is a major security problem in the modern world. Suicide bombers have a wide range of targets; they attack mosques, churches, and people in the streets, people's gatherings, buses, airplanes and so forth. They send themselves off to Paradise, as they believe, by detonating themselves among crowds of people.

The idea of going to Paradise after death and the enjoyment of all the great things there including many virgins is the main motivation of suicide bombers. Unhappiness in life, social, economic and political grievances play a minor role comparing to Paradise incentive in making Muslim individuals to kill themselves and others in suicide attacks. This Paradise incentive was what induced the Assassins in the medieval times to commit acts of suicide assassination; 
they carried out assassination against such individuals and in such places that they could not return from it or they did not want to even if they could.

By analysing the Assassins we demonstrate that suicide bombing is a transformation of suicide assassination practiced by members of this order. We argue that the method and the means of suicide murdering have changed but the idea behind it has not changed. This analysis of the Assassins will contribute to our understanding of modern suicide bombing of how individuals can be brainwashed and how this problem can be fought. The Assassins had set an example for later Muslims so this issue deserves attention. This article is largely desk-based. We review secondary sources of books, journal articles and other reliable sources available on internet. We understand that empirical method can also be used in this kind of research but we have found that the sources we use can make a good case for our research.

\section{THE ASSASSINS}

The Assassins was a radical Muslim group of the Shiite branch of Islam operated in the elevenththirteenth centuries, from 1090 to 1270 , in the northern part of modern Iran and the Levant. This order is known more for its notorious acts of assassination than for any other things, which was the assassination of prominent personalities who were often Muslims but sometimes Christians in the position of power, and assassination of ordinary people too. The assassination acts were suicidal in the sense that the Assassins were certain that there would be no return from the mission; the murder act they carried out led to their own death as well. But this was what they wanted as they were brainwashed to believe that suicide assassination was a short and definite path to Paradise. The Assassins were destroyed by the Mongols after a power struggle. The Mongols believed that the Assassins would pose a real threat to them and they were convinced that their extermination was necessary. ${ }^{1}$

During the time the Assassins existed, fear of assassination was widespread in the region and in other parts of the world. A German priest in 1332 prepared a treatise to the King of France asking him to be very cautious of a secret murderer group in the Levant when and if he wanted to recapture the holy places of Christendom. The priest who was called Brocardus named the group the Assassins and described its members as "thirsty for human blood," "suffer death as soon as they are recognised," "very skilful and dangerous" and "ruthless and competent killers.",

\footnotetext{
${ }^{1}$ Anthony Campbell, "The Assassins of Alamut".

${ }^{2}$ Bernard Lewis, The Assassins: A Radical Sect in Islam, pp. 14-15.
}

Fear and terror became widespread in the region as the result of the Assassins' assassination activity. There was widespread belief that the Assassins could strike anywhere throughout the Christian and Muslim worlds. ${ }^{3}$ One time the Old Man of the Mountain (this title referred to the leader of the Assassins) sent an agent to France on the mission of killing King Louis IX, Saint Louis, but he soon sent other agents to inform the agenton-mission not to carry out the plan. This event demonstrates how far the Assassins could reach, or at least tried to reach, places like France. Newman writes on the Assassins' terror in the Islamic world saying that their attacks were unexpected:

In their time, the Assassins managed to spread terror throughout the Islamic world. No one knew when or where they would strike. Stories were told of the fanaticism of the Assassins and of the immoral lives they led. ${ }^{4}$

The founder and first leader of the Assassins was Hassan ibnSabbah. Ibn means son in Arabic which means Hassan son of Sabbah in this context. His name is also spelt as Hasan-i Sabbah. Hassan declared his order in 1090 and continued running it until his death in 1124 . The reason why we say 'declared' is because he worked hard before 1090 to recruit people for his future order. ${ }^{5}$

Hassan was the most powerful of all the leaders of the Assassins. He was a military and theologian man. He fed his members with ideas and justifications for his plans and he was very skilful at organisation. ${ }^{6}$ Soon after he declared his order he started the art of assassination and his group became known for such thing. Members of the order started a long and very terrifying terror campaign which "brought sudden death to sovereigns, princes, generals, governors, and even divines who had condemned Ismaili doctrines."7 Ismaili doctrines constitute a branch of Shiite Islamic theology adopted by the Assassins.

Obedience is a major principle of the Ismaili doctrine. In Ismailism the knowledge that the Imam possesses is believed to be God inspired and so his orders must be followed without question because there is no single chance for error. ${ }^{8}$ Imam is a high authoritative religious figure in Shiite Islam. Hassan capitalised on this doctrine and turned his followers to become his slavelike obedient. He called them fidais (self-sacrificers), a name that is still used by modern radical groups. On one occasion and in front of several emissaries of the Seljuk

\footnotetext{
${ }^{3}$ Frank Chambers, "The Troubadours and the Assassins", pp. 24551.

${ }^{4}$ Sharan Newman, The Real History behind the Templars, p. 154

5 "History of Assassins" and Anthony Campbell, p. 10.

${ }^{6}$ Lewis, p. 167.

${ }^{7}$ Ibid.pp. 62-65.

${ }^{8}$ Edward Burman, The Assassins: Holy Killers of Islam, p. 48
} 
Sultan, Hassan nodded at a young fidaiwho responded by slitting his own throat and he singled at two others who responded by jumping off to death from the Castle of Alamut, the Assassins' headquarters. Hassan then told the emissaries that he had 60.000 men like these. Indeed, he was never short of "fanatics willing to die for his cause."1

The Castle of Alamut located in a mountain terrain in the north of Iran. Hassan bought it for three thousand dinars in gold which was a lot of money at that time. He used his wealth to get his followers a strong and unbeaten place. However, his wealth was not the only source of income of his group. There were other sources including ransom.

Like modern terrorist groups the Assassins asked for ransom from people who were often in the position of power for not being killed but unlike modern terrorist groups the Assassins did not hold the hostage in captivity. Individuals were informed by fidais that chances were high for them to be killed but they would be safe if they paid a certain amount of money.

\section{THE WORD ASSASSINS AND BRAINWASHING TECHNIQUE}

The word Assassins is used in many European languages, "it means a murderer, more particularly one who kills by stealth or treachery, whose victim is a public figure and whose motive is fanaticism or greed." Reynolds says that although the Assassins were active in the past their legacy is still with us. One legacy is their name; the word Assassins now means murderer of prominent individuals usually in a violent manner. Another legacy is that the Assassins "serve as the model for the most deadly and prevalent terrorist group at large today."

French scholar Silvestre de Sacy claims that he had finally found the true origin of the word Assassin. He says that Assassins comes from the Arabic word hashishiyyin in plural form or hashish in singular form. Hashishi means hashish-taker, and hashish is a drug. The Assassins were given hashish so they could be deceived into what Hassan told them. ${ }^{4}$ But as these hashish-takers murdered people in cold-blood the word transformed to mean murderers.

Webster and other scholars provide detail on how the Assassins used hashish (drug) on new recruits to make

\footnotetext{
${ }^{1}$ Erick Wujcik, The Palladium Book of Weapons and Assassins, p. 4 and John Reynolds, Secret Societies: Their Mysteries Revealed,pp. 2025.

${ }^{2}$ Lewis, p. 15.

${ }^{3}$ Reynolds, p. 21.

${ }^{4}$ Lewis, pp. 25-26.
}

them ready to carry out suicide assassination. According to them Hassan used the technique of giving doses of hashish to the initiates so that they would obey him and carry out his order when admitted to his group. The technique worked like this: the initiate was first taken to see the residential place of the Grand Master (Grand Master was another title of the Assassins leader), there he was given a dose of hashish without his knowledge and as the result he became unconscious, he was then taken to a Paradise-like place where everything was available including beautiful black-eyed girls. The place was similar to what described in the Quran, the Muslims' holy book, about Paradise. There were wine, honey, milk, and water and many beautiful women. When the initiate regained his consciousness he found himself in Paradise, surrounded by beautiful girls and everything was at hand. The initiate was then given another dose of hashish, again without his knowledge, and taken back to the Grand Master. When he regained consciousness the Grand Master explained to him that he did not go physically anywhere but he, at the Grand Master's presence, experienced a sample of Paradise that awaited him if he fully obeyed the orders of his masters. ${ }^{5}$ The initiation was usually followed by taking the oath of allegiance to the Grand Master.

Some authors argue that the Assassins also used hashish on their members when they were on the mission of suicide assassination. What they normally did was that they put their subject in a state of hypnosis, used certain drugs to make him strong and effective, and they gave him suggestion that could be triggered by a word at any time so that he could jump into action. ${ }^{6}$

In addition to this the Assassins operated secretly during assassination mission. Members of the order who were given the task of assassination had to disguise themselves under different names, mix with local people and learn their language if needed and sometimes waited for a long time until they got the opportunity to do the murder. So the nature of the work required the adoption of secret methods. "You cannot fight what you cannot see." 7

\section{TERRORISM THROUGH ASSASSINATION AND AFTERMATH}

Assassination was not the invention of the Order of the Assassins but organised suicide assassination for a long period of time was its. The Assassins was the first group to do "systematic implementation of political

\footnotetext{
${ }^{5}$ Nesta Webster, Secret Societies and Subversive Movements, p. 28, Philip Gardiner, Secret Societies: Gardiner's Forbidden Knowledge, p. 110 and Wujcik, p. 5.

${ }^{6}$ Haha Lung, Assassin: The Deadly Art of the Cult of the Assassins, p. 67 and Nick Harding, Secret Societies, p. 24.

${ }^{7}$ Lung, p. 2 and Harding, p. 23.
} 
assassination." Hassan, the leader, used assassination to strike "horror into the hearts and imagination of his contemporary...it is for this that his sect became known and feared in the West and generated legends." "Leaders of the group had political goals to achieve but not the fidais, the self-sacrificers, who carried out suicide assassination to get to the Paradise they falsely experienced during the initiation process.

The Assassins made assassination its profession. It practiced it for a long time as its sole weapon to terrorise its enemies and the population in general. Just to remember, the Assassins were suicide murderers because they carried out assassination in such places that they could not escape; they were killed by their enemies at the scene. According to Erick Wujcik, the Assassin, like many terrorist organisations today, "used assassination as a tool of terrorism."2

The Assassins were no match for the superior armies of their enemies, yet with their fidais, who often spent months to infiltrate the enemies and stab their victims to death, they terrorised the whole Middle East, "even the most powerful and carefully guarded rulers of the age lived in dread of the chameleon-like Assassins agents." 3

The Assassins used another terrorisation tactic. "Often the lord of Alamut could channel the course of history simply by a mysteriously placed massage, significantly transfixed by a dagger." It generally worked like this: the Assassins used its secret agents close to the person whom they wanted to terrorise to place a dagger with a message near his head while he was asleep. When the person woke up and saw the dagger with the message he became terrorised and understood that the close people around him had among them agents of the Assassin. ${ }^{5}$

The Assassins used terrorism not just against outsiders but against those members who did not follow instructions of the Grand Master. One example is that during the reign of Muhammad II 250 members were executed and 250 more were ordered to carry the corpses of the 250 executed ones and they were sent to exile. These people were punished this way because they had different interpretation for a declaration by Muhammad who announced that neither himself nor his son were the imam. ${ }^{6}$

For a terrorist organisation to exist there must not be any affection or sympathy whatsoever for they carry out merciless attacks. If mercy or affection exists members of a terrorist group might not then be able to do the

\footnotetext{
${ }^{1}$ Burman, pp. 37-38.

${ }^{2}$ Wujcik, p. 5.

${ }^{3}$ Jefferson M. Grey, "Holy Terror: The Rise of the Order of Assassins".

${ }^{4}$ Lung, p. 18.

${ }^{5}$ Ibid. p. 2.

${ }^{6}$ Campbell, p. 22.
}

missions they are given. The Assassins set a bad example for the later terrorist organisations in that regard. Hassan, the founder and the leader, executed his three sons, one on murder charges which later proved to be false and the other two were executed for drinking wine. Historian von Hammer suggests that Hassan's execution of his own sons was "a deliberate effort to inculcate in the community a disregard for all natural bonds of affection."

The first suicide assassination act by the Assassins was the murder of the statesman Nizam al-Mulk, the Seljuk ruler in Persia. He was cold-bloodedly murdered in 1092 by an Assassins disguised himself as a Sufi submitting a petition. ${ }^{8}$ The Assassins was killed at the scene in retaliation. In reaction to the murder of al-Mulk the Seljuk Sultan Malik Shah-the dominant power in the Middle East-launched a massive aggression against the Alamut. After two months of assault and failure Malik Shah had a meeting with his generals in which he discussed their unsuccessful military operations but he drank a cup of water and immediately died. It was understood that his glass was poisoned by the Assassin. The death of two high figures brought about chaos among the Seljuks: "Power slipped into the hands of regional Seljuk rulers who immediately split into warring factions over the question of who should rule after Malik Shah...this successional infighting further weakened the Seljuk influence in Persia and Iraq." "Gray writes on the Assassins and their violence in connection to this event:

Over the next century, as other fida'is followed in $\mathrm{Bu}$ Tahir's footsteps [Bu-Tahir was the Assassins who murdered Nizam al-Mulk], caliphs, viziers, generals, emirs, urban and religious leaders, and even Christian princes fell to their daggers, and their sect came to be known by the chilling sobriquet, the "Order of Assassins." 10

Nizam al-Mulk, original name Abū'AlīHasanibn 'AlīibnIshāà al-Ṭūsī (1018/19-1092), is best remembered for his treatise Seyāsat-Nāmeh (The Book of Government). Al-Mulk occupied the position of vizier for 30 years. He was the corner stone of the empire. With his wisdom and great knowledge he "guided the sultan's decisions, sometimes even military ones, and his firm control of the central and provincial administration, through his numerous dependents and relatives, implemented those decisions." During his time "the Seljuk Empire was at its zenith."11

\footnotetext{
${ }^{7}$ Marshall Hodgson, The Order of Assassins; the Struggle of the Early Nizârî Ismâ '̂llîs against the Islamic World, p. 51.

${ }^{8}$ Ibid. p. 75.

${ }^{9}$ Lung, p. 19.

${ }^{10}$ Jefferson M. Grey, "Holy Terror: The Rise of the Order of Assassins".

11"Nizam al-Mulk".
} 
The Seljuk Empire became stronger internally and expanded externally to an extent that it bordered China in the East and Byzantines in the West. Toghril Beg and Malik-Shah's reigns were considered as the golden age thanks Nizam al-Mulk who served both of them. AlMulk helped the growth and advancement of the empire a lot. He was the mind behind the empire. Now on the peak of that the Assassins "started to become a force during his era and assassinated many leading figures in his administration" including himself. ${ }^{1}$

Thus the assassination of this man is considered a great and un-repairable loss for the Seljuk Empire. The Britannica has written the following lines about the service al-Mulk offered to the Seljuk Empire:

Nizāam al-Mulk expressed his religious devotion in ways that contributed to the Sunni revival. He founded Nizāmiyyah madrassas (colleges of higher learning) in many major towns throughout the empire to combat Shī ite propaganda, as well as to provide reliable, competent administrators, schooled in his own branch of Islamic law. Less orthodox religious communities among the Sufi orders also benefited from his generosity; hospices, pensions for the poor, and extensive public works related to the pilgrimage to Mecca and Medina were created or sustained by his patronage. Particularly in his last years, when the Ismā $\mathbf{1} l \overline{1}$ threat grew stronger and its partisans found a refuge in Alamūt, the castle of the Assassins, he set himself the task of combating their influence by every means possible. ${ }^{2}$

Assassination had proved to be an effective and successful weapon of the Assassin. The reason was because within the Muslim world power and authority were often "invested in the person who managed first to gain and then to keep it." When the founder of a monarchy, for example, died or killed the future of the monarchy was in jeopardy; it soon started to decline and disappeared. This made assassination an effective weapon "since the removal of a single person could throw a situation into turmoil and the whole process had to start again." ${ }^{3}$ The weapon of assassination had also worked to create mistrust among elites in the Middle East and in Europe; "numerous rulers or leaders were accused of being in league with the Old Man and of employing the services of his emissaries to destroy an inconvenient enemy."

However, assassination as a weapon worked against the Assassins itself and against the wider Shiite

\footnotetext{
"'Seljuk Turks", "History of Anatolian Seljuks" and "The Seljuk Empire".

"Nizam al-Mulk".

${ }^{3}$ Burman, p. 37.

${ }^{4}$ Lewis, pp. 23-24
}

population too. The group was hated by many and innocent people of the Shiite often became victims as they were targeted in retaliation campaign by the Sunni armies. A number of massacres happened at different times and in different places in which thousands of suspected Assassins were slaughtered. Innocent people were sometimes caught up in the fight and murdered. In one case a number of Sufis were murdered because the Assassins who carried out the murder act was wearing Sufi grab and for a time it was thought that the Sufis were behind the killing. ${ }^{5}$ In another example in 1142 during the reign of BuzurgUmid, the first successor of Hassan ibnSabbah, the son of the Shah Ghazi Rustam of Mazandaran was assassinated by the Assassins. In revenge, Shah dedicated the rest of his life to oppose the Assassins. It is mentioned by the Assassins chroniclers that Shah Ghazi "built several towers of Ismaili heads." Terror and violence also made the division between Islamic sects much wider. ${ }^{7}$

Violence begot violence. In Hodgson's words "the public...regarded this as one scourge scourging another." " The Assassin's acts were violent and were the reactions, this situation continued in a vicious circle. Although we cannot accurately measure the impact of this situation on politics and life in general at that time we can say that political instability was one of the consequences. Added to that was the spread of fear and insecurity in the wider region.

\section{ASSASSINS AND MODERN SUICIDEBOMBERS}

In this section we look at the similarities between the agents of the Assassins and modern suicide bombers. For a start, we do not claim that modern suicide bombers are descendents of the Assassins; so the word 'ancestors' mentioned in the title does not have a literal meaning in the context of this research. It is used figuratively. Besides, there is a big distance of time between the two periods, eleventh-thirteenth centuries to twenty-twenty-first centuries.Also the Assassins were Shiite Muslims and modern suicidebombers are largely Sunni Muslims. However we argue that suicide bombers' methods and actions resemble those of the Assassins. Here we try to show that suicidemurder is not a new phenomenon. It goes back to the Assassin.

Jefferson Grey describes the relationship is another way. He uses the word "echo" to link modern terrorist groups to the Assassins. He says that terror acts by the Assassins find echoes in today terrorist actions. ${ }^{9}$

\footnotetext{
${ }^{5}$ Hodgson, p. 121.

${ }^{6}$ Ibid. p. 145.

${ }^{7}$ Newman, p. 150

${ }^{8}$ Hodgson, p. 147.

${ }^{9}$ Jefferson M. Grey, "Holy Terror: The Rise of the Order of Assassins".
} 
There are two main similarities between the Assassins and modern suicidebombers and there are two differences but they are differences in detail not in principle. One similarity is that both the Assassins and suicide bombers were and are convinced that they will go to Paradise upon their death. Another similarity is their actual death in action; i.e. the Assassins carried out assassination in such places and among such people that they could not escape from death; they were immediately killed, or tortured to death, by the guards or followers of the person whom the Assassins murdered, "The Assassins is almost always caught, and usually indeed makes no attempt to escape; there is even a suggestion that to survive a mission was shameful."1 Newman agrees with this point and argues that the Assassins wanted death for their victims as well as for themselves; it was a point of honour that they faced their victims who were usually well guarded. For this reason, the assassinations were considered suicide missions. ${ }^{2}$ Modern suicide bombers wear explosive belts and detonate themselves among crowds of people. They kill themselves and others. The Assassins and suicidebombers differ in two aspects in the detail of action. One difference is that the Assassins chose their victims carefully, often from the elite. They often attacked the following groups: military chiefs, local community leaders, sultans, those who opposed them, those who incited people against them, judges and the like. And sometimes they carried out murder for symbolic reasons like the murder of two caliphs of Baghdad. The Assassins were also targeting persons who had learned about them and wanted to reveal information. ${ }^{3} \quad$ Today suicide bombers kill indiscriminately. They kill as many people as possible in a single action. ${ }^{4}$ Another difference is that the Assassins were just using one kind of weapon, dagger, while it was available for them bow and crossbow, sword and other weapons. Modern suicidebombers use all sorts of explosives and other weapons to maximise their casualties. $^{5}$

Historian Barry Sadler is quoted saying that agents of the Assassins carried out suicidemurder attacks and they were enthusiastic about it:

Assassins. One never knew when they would strike, and there was nothing that could be done to scare them off. Indeed, when captured they went to their deaths eagerly, joyfully. How can one deal with men who do not fear death? What was the power the Old Man of the Mountain had over his followers that they obeyed his

\footnotetext{
${ }^{1}$ Lewis, p. 163.

${ }^{2}$ Newman, p. 150

${ }^{3}$ Hodgson, p. 112

${ }^{4}$ Robert A. Pape, "The strategic logic of suicide terrorism", p. 345.

${ }^{5}$ Lewis, p. 12.
}

every wish without consideration of their own lives. ${ }^{6}$

This description of the Assassins can apply on modern suicidebombers. Suicidebombers are almost impossible to be scared off from their attacks. They know that they will die but they are ready and willing to do so, and they call it martyrdom, not a simple death.

"The concept of the shahid[somebody who gets martyrdom] or martyr is, by Islamic definition, a warrior killed by the enemy in battle in the name of Allah. This entitles him to life after death in paradise with 70 of his dearest relatives and friends and the pleasure of 72 virgins."7

To define suicide bombing, it is an attack that is "politically motivated, [it is a] violent attack perpetrated by a self-aware individual who actively and purposely causes his own death by blowing himself up along with his chosen target. The perpetrator's death is a precondition for the success of the mission." 8 Durkheim contends that

Altruistic suicide may actually spring from the hope and belief that there is a beautiful life after death. For suicide bombers, the belief in becoming a martyr following death can in some cases be enough to engage in the suicide attack. Suicide for martyrdom is also labelled acute altruistic suicide. ${ }^{9}$

Reporting on the young Muslim Palestinian bombers Suzanne Goldenberg writes in the guardian:

The friends and families of suicide bombers say they killed themselves as an act of absolute faith: martyrdom, not suicide. "According to Islam, he will be married to 70 virgins and he will not be dead. He will be alive with God," says a friend of the first bomber of this intifada, Nabil Arir. "It is an honour to be able to blow yourself up this way," says the friend, an activist of Islamic Jihad, who says his name is Mohammed. ${ }^{10}$

Goldenberg writes that the terrorist Muslim organisations in Palestine had a process of selection of young Muslims for the act of suicide bombing. They fist chose them and isolated them for a month from their families and friends so that they could well indoctrinate them. They were been shown videos of previous bombings and "they were taken to cemeteries and told to lie in a grave for several hours to overcome their fear of death." 11

Michelle Maiese argues that there is no single motive for suicide bombers. There are multiple motives and factors involved in motivating certain individuals to

\footnotetext{
${ }^{6}$ Lung, p. 7.

${ }^{7}$ MeytalGrimland, Alan Apter, and AdKerkhof "The Phenomenon of Suicide Bombing: A Review of Psychological and Nonpsychological Factors".

${ }^{8}$ Ibid.

${ }^{9}$ Nicholas W. Bakken, "The Anatomy of Suicide Terrorism: A Durkheimian Analysis", p. 3.

${ }^{10}$ Suzanne Goldenberg, "The men behind the suicide bombers".

${ }^{11}$ Ibid.
} 
commit acts of suicide bombing. But ideology is a big motive. Individuals are motivated to believe that a much better life is awaiting them in the afterlife and they believe that self-sacrifice is a glory. Other reasons are social and cultural; suicide bombers believe that by committing such actions "They will be heroes, they will help the cause of their group."

Suicide bombers and terrorist organisations in general pose a great threat to the world peace and security in our time. According to some reliable date, "between 1981 and 2006, 1200 suicide attacks constituted 4 percent of all terrorist attacks in the world and killed 14,599 people or 32 percent of all terrorism related deaths."

What overshadows the agenda of many governments around the world now is how to encounter and overcome this threat. Muslim suicidebombers have struck the heartland of the Western world in the twentyfirst century. At the dawn of the century the whole world woke up to the threat of Islamic radical groups whose agents are ready to kill and die in action. The problem is very wide to an extent that no country nowadays feels safe from this threat. This form of terrorism, however, is not new. It has a deep root in history as we show in this research. We can go back to the eleventh century to the castle of Alamut and see that a sophisticated organization terrorised the entire population in the region by committing acts of suicide assassination.

The Assassins were "the first to create an effective and enduring organisation." ${ }^{3}$ They were the first who terrorised the region for a long time by carrying out systematic assassination. The Assassins always had terrorists willing to die upon the command of the Grand Master. Similar to today suicide bombers agents of the Assassins were sure that they would not return from their assassination activity but they were well prepared and ready to take it.

Agents of the Assassins were lured by their leader to a point that they preferred to die sooner as they believed that a much better and enjoyable world was awaiting them. This is why they killed without questions and died in action. We can see how the same idea of a better world after death, Paradise, is propagated by modern terrorist groups. The suicide bombers of terrorist Islamic groups believe that by blowing up themselves among crowds, killing themselves and whoever around, they will be given a special place in Paradise. They believe that their leaders guide them to the right path, the path of pleasing God by fighting his enemies. Some failed suicide bombers who were interviewed later admitted

\footnotetext{
${ }^{1}$ Michelle Maiese, "Suicide Bombers".

${ }^{2}$ Yale Global Online.

${ }^{3}$ Lewis, p. 164.
}

that they became more religious before their failed attempts to detonate themselves and they wished for martyrdom. ${ }^{4}$

The techniques used by Hassan, founder and first leader of the Assassin, to prepare his followers to kill and be killed were rather peculiar and time-consuming but this is no longer required. Today young Muslims can be convinced by just words to become suicidebombers. Leaders of the terrorist groups incite them to believe that they would go straight to Paradise if they die in fighting the enemies of God which is the larger society according to them. Some might doubt that Hassan actually needed to use the kind of brainwashing technique we talked about earlier. The reason is because they think that the Assassins were like today suicide bombers who could be convinced just by words, so the long process of drugging and experiencing the illusion of Paradise in the castle is not necessary any more.

And for some other people it is hard to believe that Hassan had young men willing to sacrifice their lives upon his order. However looking around these days we can see young men and occasionally women blow up their bodies among crowds of people in the streets of Baghdad, Istanbul and many other places, "in the belief that they will be transported instantly to Paradise."

Hassan ibnSabbah developed two strategies which later defined his group and the same strategies can define modern terror groups. The first strategy was that Hassan created an ideological atmosphere in which he received a constant supply of volunteers ready to sacrifice their lives. And the second strategy was that he instructed his men to murder selected victims in public places and at busy times such as Friday prayers to terrify people and make leaders feel unsafe. We can see that these two strategies find replica in modern terror groups. Modern terror groups use ideology to recruit young people to suicidebombing missions to cause immense terror. ${ }^{6}$ Another thing that has replica in modern terror groups is "fanatical dedication to an ideal, to a worthy cause or a respected leader.",

Assassins and assassinations are all around us. In a country like Iraq killing innocent people happens almost every day. There are many brainwashed terrorists who blow up themselves and kill a large number of people. The art of assassination is very old but assassination of individuals or killing people in mass by the Assassins and by modern suicidebombers were and are ideologically driven, politically motivated and

\footnotetext{
${ }^{4}$ Robert J. Brym and Bader Araj, "Are suicide bombers suicidal”.

${ }^{5}$ Reynolds, p. 34.

${ }^{6}$ Jefferson M. Grey, "Holy Terror: The Rise of the Order of Assassins".

${ }^{7}$ Lung, p. 16.
} 
systematically performed. Under the leadership of their leader, Hassan ibnSabbah, the Assassins created the first wave of systematic assassination in what we now call the Middle East and it lasted for many decades. Modern suicide bombers are worse than them as they kill people indiscriminately; they kill bystanders, children and the so on.

The Assassins came into contact with the Western world after they stretched to the Levant. Members of the order in the Levant occupied a number of castles and they slowly became relevant to the problems there. The Christians and Muslims were in constant conflict over the Holy Land and there were other conflicts as well. The Assassins were not a main party of these conflicts but they had their own contribution. It is more the Levant than Persia that introduced the Assassins to the West and to the wider Muslim community.

\section{ASSASSINS IN THE LEVANT}

The Assassins had its main headquarters in the Castle of Alamut in Persia but it had an active branch in the Levant which operated under its direction but sometimes behaved as an independent body. ${ }^{1}$ The story began when early Assassins propagandists were sent from Alamut to the Levant in the early years of the twelfth century by Hassan ibnSabbah. Same like Persia, the Assassins in the Levant began killing important Sunni political figures in cold-blood. In 1110 the Assassins in Aleppo murdered a Persian traveller. People were outraged when they heard the news and the governor could not stop angry people from committing a massacre against suspected members of the order in Aleppo. This incident introduced the Assassins to the people of Aleppo and revealed its identity at the same time. ${ }^{2}$ The Assassins in the Levant tried to follow their head in Persia in terms of fortifying their positions and strongholds. They did this by controlling a number of fortresses close to each other so that each could support the other in times of war and peace. They also created cells and they could bounce back occasionally from defeats they had suffered at the hands of local rulers.

The story of the Assassins in the Levant is not so much about assassination although assassination remained its core mission. The story is more about how this group survived and what kind of role it had in the relationship and the balance of power between the opposing forces in the area.

The long-time leader of the Assassins in the Levant was a man called Rashid al-Din Sinan from 1163 to 93. His full name was Sinanibn Salman ibn Muhammad. He was originally from Basra, south of modern Iraq. There are controversies about how he became the leader of the

\footnotetext{
${ }^{1}$ Burman, p. 119.

${ }^{2}$ Burman, p. 95.
}

group but it is confirmed by historians that he gained the position with the blessing of Alamut, and he had a good relationship with Hassan II, a successor of Hassan ibnSabbah, for some time.

As the leader of the Assassins in the Levant Sinan was able to show a strong leadership and hold his people together. His followers had a strong belief in him and attributed to him characteristics that could be counted as super-human. There were stories about him which are thought to have been made to create the illusion that he was gifted by God special traits and so he could perform actions that were impossible for other human beings to do. ${ }^{3}$

Sinan made two separate deals which helped a lot his and his group's survival. One deal was with the King Amarlic I of Jerusalem in 1174. According to which the Assassins would provide intelligence to Amalric in his fight against Nur el-Din, an Egyptian Muslim Sunni warlord who opposed both the Assassins and the Christians. Also, the Assassins would train members of the Amalric forces on "tactics and techniques of the Assassins." In return Amalric would stand shoulder to shoulder if the Assassins' strongholds were attacked. Another deal was with Saladin, the famous Muslim warrior and leader who unified the Muslim forces and was able to drive the Christian Crusaders out of the Holy Land. According to this deal both sides would not fight each other. These two deals secured the survival of the Assassins in the Levant during the reign of Sinan. ${ }^{4}$ Emboldened Sinan sent a letter to Nur el-Din warning him that they were not an object for attack and that they were not intimidated by their might. He made it clear that his men would stand strong in the face of aggressions. $^{5}$

However, these two deals had other consequences apart from the survival of the Assassin. The deal with King Amarlic I of Jerusalem worked against Nur el-Din and weakened him and the deal with Saladin freed the latter from local rivalries and internal problems to focus solely on the Christian Crusaders.

The deal with Saladin did not come easily, however, and it did not last long. Saladin came into conflict with the Assassin. Sinan soon dispatched agents to kill him. On two occasions in 1176 Saladin was attacked by Assassins agents but he survived although many of his guards and comrades were killed. ${ }^{6}$

In 1176 Saladin decided to finish the Assassins "once and for all." He laid siege on their stronghold in Masyaf. But after sometime of siege and after exchanging some letters with Sinan it became clear for Saladin that Sinan

\footnotetext{
${ }^{3}$ Campbell, pp. 32-36.

${ }^{4}$ Lung, p. 39.

${ }^{5}$ Campbell, p. 39.

${ }^{6}$ Ibid. p. 40.
} 
could not be destroyed. They reached some sort of truce. There is a view which argues that accepting not to attack the Assassins in return for not being attacked meant that one of the great military rulers in the Islamic history surrendered to a terrorist group. ${ }^{1}$ This can be interpreted as a sign of strength for the Assassins.

The Assassins in the Levant left its own marks on politics and on the balance of power between different forces existed in the region. The new ruler of the Crusaders, Conrad Montferrat, was murdered in 1192 by the Assassins agents. This incident brought to the Christians an ever-lasting defeat because Conrad was a match of Saladin. In another word, had not the Assassins murdered Conrad it might not have been possible for Saladin to capture Jerusalem. His murder also brought the Assassins to the Western attention. ${ }^{2}$

\section{ASSASSINATION ACTIVITY IN THE LEVANT}

In this section we examine the Assassins in the Levant against the Sunni Muslim powers, the Christian Crusaders, sometimes referred to as the Franks, and a military group of the Franks called the Knights Templar. The Persian Assassins were far from the Crusaders' territories so they did not have much to do with them but the Levantine Assassins were quite close, therefore coming into contact with the Crusaders was unavoidable. If not for the Assassins in the Levant the Europeans might not have known or developed stories about them. The Assassins in the Levant and Christian Crusaders came to fight each other on a number of occasions. The Assassins were in possession of a number of castles from which they launched attacks.

The assassination of the King of Jerusalem Conrad Montferrat in 1191 (it was in 1192 according to some references) by the Assassins is one of the often told stories about the threat and danger this organisation posed to the Franks. This murder happened in a way that turned to be very shocking and unexplainable for the king's personal guards and for those who later heard it. Three Assassins disguised as monks were allowed to approach the king. The 'monks' made signs of the cross and passed the security barriers. Once they reached Conrad they withdrew daggers and cut him to pieces in a very savage manner before the security guards could stop them. When they finished their job they did not try to escape or even resist being captured. They surrendered to the guards and smiled in the face of the punishments awaiting them. They wanted to die so that they could attain Paradise. The three Assassins were

\footnotetext{
"'History of Assassins".

${ }^{2}$ Jefferson M. Grey, "Holy Terror: The Rise of the Order of Assassins".
}

407 burned to death in retaliation for the murder. Later the guards stayed bewildered at what happened. It was unexplainable and unspeakable for them. ${ }^{3}$

The assassination of Count Raymond II of Tripoli by the Assassins in 1152 is another incident that alarmed the Franks. While he was on his way back to Tripoli a group of Assassins stopped him and killed him and killed his two guards as well. The Franks reacted not just against the Assassins but against all Muslims. ${ }^{4}$

Despite these murders the number one target of the Assassins was Sunni Muslim leaders. The fight against the Sunnis worked sometimes in favour of the Christians although this did not seem to be the intention of the Assassins. Burman mentions by name a number of important Sunni leaders who were murdered by the Assassins in the Levant in the twelfth century and argues that this number of death was "advantageous to the Christian crusading forces in destabilizing the delicate equilibrium between Muslim rulers in the area." Also, agents of the Assassins murdered several Christian leaders as well which had huge consequences for the balance of power between the Muslims and the Christians. Conrad of Montferrat, we mentioned earlier, was murdered in 1192 by the Assassins in Tyre. He "was recognised by the Crusaders as the ideal man to oppose Saladin" and his murder was described as a "serious blow to the renascent Kingdom of Jerusalem." Burman points out that this murder was such a big blow to the crusading forces that they "never recovered" and they lost a chance to recapture Jerusalem. ${ }^{5}$

In the late twelfth century Saladin appeared as the architect and unifying leader of Muslims against the Crusaders. ${ }^{6} \mathrm{He}$ saw the Assassins as a threat. He mobilised his troops and tried to capture their strongholds but he soon withdrew because he needed them for other battles or because of other reasons. ${ }^{7}$

To summarise, the Assassins in the Levant were able to carry out a number of suicide assassination or suicide assassination attempts. Their murder actions did not only result in the loss of lives but the instability in the region too. Assassination acts and plots made the region more unstable, it worsened the relationship and trust between the communities lived there and it somehow changed the balance of power between the rival forces, the Muslims and Franks.

\footnotetext{
Reynolds, pp. 18-19.

${ }^{4}$ Campbell, p. 42.

${ }^{5}$ Burman, pp. 100-101.

${ }^{6}$ Lewis, p. 149.

${ }^{7}$ Burman, pp. 116-117.
} 


\section{CONCLUSION}

Suicide bombing is a major characteristic of modern Islamic terrorism. Radical Muslims, often young, carry explosives and detonate themselves among crowds of people. They cause immense casualties and destruction. Suicidebombers have attacked different parts of the world. It seems that no country nowadays is immune from this threat. Governments around the world take tough security measures to encounter this problem but it does not seem that they can overcome it any soon because this problem has little to do with the bad conditions of life or unpleasant circumstances under which Muslims live, it has more to do with the conviction in going straight to Paradise by committing suicide bombing attacks.

It is true that bad conditions of life or unpleasant circumstances can be exploited by radical Muslims to recruit individuals to their terrorist networks but it is the Paradise incentive, the belief in the access to all the joys there upon death, that convinces these individuals to join them and commit suicidebombing, kill themselves and the people around. Suicide bombing or suicide assassination is not a new phenomenon. It is only new in form, in using explosives and modern devices; suicide attack was practiced hundreds of years ago by the Assassins who mainly had behind their acts the same driving force. That driving force was the belief in immediate access to Paradise.

The Assassins and modern terrorist organizations were and are not short of men ready to hide daggers or wear explosive belts under their clothes and commit suicide attacks. The Assassins and modern suicide bombers do not want to die in self-suicide act because self-suicide is not approved in the Islamic religion. Instead they want to die in suicide attacks which mean killing people together with themselves. This is justified by them because they see the whole society, apart from themselves, as not true believers who deserve to die and be used as a ladder to climb to Paradise.

Mohammed Atta, leader of 9/11 suicide bombing group, wrote a letter before he hijacked planes into the World Trade Centre. The letter"does not speak of hatred. It is past hatred. Absurdly and perversely, it is about love; the love of God."He mentions in the letter "God's satisfaction" and the things that men can do to "enter God's eternal paradise."1 According to a report, many Palestinian suicide bombers' last words to their friends and masters were"Inshallah, we will meet in

\footnotetext{
${ }^{1}$ MeytalGrimland, Alan Apter, and AdKerkhof "The Phenomenon of Suicide Bombing: A Review of Psychological and Nonpsychological Factors". 408
}

Paradise."

Admittance to Paradise in the afterlife is the ultimate aim of all Muslims who believe that God will give it only to those who worth it. Any kind of certainty regarding Paradise admittance is eagerly welcomed by them. Leaders of the Assassins and the modern suicide bombers play on this line and they manage to exploit it in favour of their own political agenda. Leaders of the Assassins used special techniques and leaders of modern suicide bombers manipulate religious texts to radicalise people and recruit them to their organisations. For the agents of the Assassins and for individual suicide bombers the political agendas of their leaders do not matter so much because after all they seek Paradise, and what their leaders make of their actions is not their concern. This Paradise incentive has been the focus of this article and we recommend it to be the focus of other articles in the future about how to fight or how to overcome suicide bombing in particular and Islamic terrorism in general.

Maybe one way to undermine the idea that promotes suicide bombing is to work on the culture to accept humour about the heroes and other influential persons. Christianity and Judaism, according to Ariel Glucklich, "have evolved a very powerful tradition of comedy that undermines the heroic stature of someone who presumed to be the Messiah." 3 This can also be something to look at by future researchers

\section{REFERENCES}

Basic format for books:

[1] Alyssa Fetini, "Inside the mind of a suicide bomber". Available at

http://content.time.com/time/world/article/0,8599,1934101,00.ht $\mathrm{ml}($ accessed 5 October 2016).

[2] Anthony Campbell, "The Assassins of Alamut". Available at http://www.iranchamber.com/history/ismailieh/books/the_assassi ns_of_alamut.pdf(accessed 14 January 2014).

[3] Bernard Lewis, The Assassins: A Radical Sect in Islam (New York: Basic Books, 2003).

[4] Edward Burman, The Assassins: Holy Killers of Islam (S.1.: Crucible, 1987), p. 48.

[5] Erick Wujcik, The Palladium Book of Weapons and Assassins (Detroit: Palladium Books, 1983).

[6] Frank Chambers, "The Troubadours and the Assassins", Modern Language Notes 64, No. 4, April 1949.

[7] Haha Lung, Assassin: The Deadly Art of the Cult of the Assassins (New York: Citadel, 2004).

[8] "History of Assassins", Christian History Project. Available at http://www.christianhistoryproject.org/the-crusades/secondcrusade/history-of-assassins/(accessed $21 \mathrm{Feb} 2016$ ).

[9] "History of the Anatolian Seljuks". Available at http://www.turkishhan.org/history.htm(accessed 2 July 2016).

[10] Jefferson M. Grey, "Holy Terror: The Rise of the Order of Assassins", History Net. Available at:http://www.historynet.com/holy-terror-the-rise-of-the-orderof-assassins.htm (accessed 21 December 2015).

\footnotetext{
${ }^{2}$ Nicholas W. Bakken, "The Anatomy of Suicide Terrorism: A Durkheimian Analysis", p. 8

${ }^{3}$ Alyssa Fetini, "Inside the mind of a suicide bomber".
} 
JUHD / Vol. 2, No. 4, December 2016: pp 399-409

e-ISSN: 2411-7757, p-ISSN 2411-7765

[11] John Reynolds, Secret Societies: Their Mysteries Revealed (Chichester: Summersdale Publishers, 2007).

[12] Marshall Hodgson, The Order of Assassins; the Struggle of the Early Nizârî Ismâ îlî̀ against the Islamic World (Gravenhage: Mouton, 1955).

[13] MeytalGrimland, Alan Apter, and AdKerkhof, "The Phenomenon of Suicide Bombing: A Review of Psychological and Nonpsychological Factors", Crisis 2006; Vol. 27(3).

[14] Michelle Maiese, "Suicide Bombers". Available at http://www.beyondintractability.org/essay/suicidebombers(accessed 11 Oct 2016).

[15] Nesta Webster, Secret Societies and Subversive Movements (Costa Mesa, CA: Noontide Pr., 1990).

[16] Nick Harding, Secret Societies (Harpenden, Herts.: Pocket Essentials, 2005).

[17] Nicholas W. Bakken, "The Anatomy of Suicide Terrorism: A Durkheimian Analysis", International foundation for Protection Officers, August 2007.

[18] Nizam al-Mulk.

Available at https://www.britannica.com/biography/Nizam-al-Mulk-Seljuqvizier (accessed 3 July 2016).

[19] Philip Gardiner, Secret Societies: Gardiner's Forbidden Knowledge (London: Bounty, 2009).

[20] Robert A. Pape, "The strategic logic of suicide terrorism", American Political Science Review Vol. 97. No. 3, August 2003.

[21] Robert J. Brym and Bader Araj, "Are suicide bombers suicidal", Studies in Conflict and Terrorism, 35:432-443, 2012.

[22] "Seljuk Turks". Available athttp://www.newworldencyclopedia.org/entry/Seljuk_Turks(acc essed 2 July 2016).

[23] Sharan Newman, The Real History behind the Templars (New York: Berkley Books, 2007)

[24] Suzanne Goldenberg, "The men behind the suicide bombers". Available

https://www.theguardian.com/world/2002/jun/12/israel1(accesse d 2 October 2016)

[25] "The Seljuk Empire". Available athttp://www.allempires.com/article/index.php?q=Seljuk_empire (accessed 2 July 2016)

[26] Yale Global Online. http://yaleglobal.yale.edu/content/whatmotivates-suicide-bombers-0 (accessed 11 Oct 2016). 